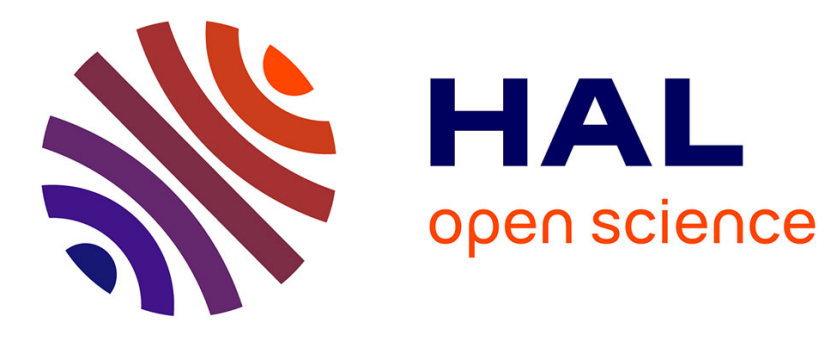

\title{
Cistus ladanifer (Cistaceae): a natural resource in Mediterranean-type ecosystems
}

\author{
David F. Frazão, Joana R. Raimundo, Joana L. Domingues, Celestino \\ Quintela-Sabaris, José C. Gonçalves, Fernanda Delgado
}

\section{- To cite this version:}

David F. Frazão, Joana R. Raimundo, Joana L. Domingues, Celestino Quintela-Sabaris, José C. Gonçalves, et al.. Cistus ladanifer (Cistaceae): a natural resource in Mediterranean-type ecosystems. Planta, 2018, 247 (2), pp.289-300. 10.1007/s00425-017-2825-2 . hal-02011388

\section{HAL Id: hal-02011388 \\ https://hal.science/hal-02011388}

Submitted on 7 Feb 2019

HAL is a multi-disciplinary open access archive for the deposit and dissemination of scientific research documents, whether they are published or not. The documents may come from teaching and research institutions in France or abroad, or from public or private research centers.
L'archive ouverte pluridisciplinaire HAL, est destinée au dépôt et à la diffusion de documents scientifiques de niveau recherche, publiés ou non, émanant des établissements d'enseignement et de recherche français ou étrangers, des laboratoires publics ou privés. 


\title{
Cistus ladanifer (Cistaceae): a natural resource in Mediterranean-type ecosystems
}

\author{
David F. Frazão ${ }^{1}$ Joana R. Raimundo ${ }^{1}$. Joana L. Domingues ${ }^{1}$. Celestino Quintela-Sabarís ${ }^{2}$ José C. Gonçalves ${ }^{1,3,4}$. \\ Fernanda Delgado ${ }^{1,3,4}$ (D)
}

Received: 26 July 2017 / Accepted: 27 November 2017 / Published online: 7 December 2017

(c) Springer-Verlag GmbH Germany, part of Springer Nature 2017

\begin{abstract}
Main conclusion Cistus ladanifer has a well-defined taxonomic identity. 2,2,6-trimethylcyclohexanone may be an authenticity and taxonomic marker. Its traits and applications make it a possible economic resource fitted for Mediterranean areas.
\end{abstract}

Cistus ladanifer is a dominant shrub species endemic to the western Mediterranean region. Due to its dominant nature and its potential ecological, aromatic or pharmacological applications, C. ladanifer has been the object of numerous studies. In this review current knowledge on different aspects of this species is summarized, from its taxonomy to its chemical characterisation or its competitive traits. There are no doubts about the taxonomic entity of $C$. ladanifer, although the recognition of infraspecific taxa deserves more attention. Given that the fragrant exudate of $C$. ladanifer holds a very specific composition, one species specific carotenoid, 2,2,6-trimethylcyclohexanone, derivative is proposed as an authenticity marker for uses of C. ladanifer in pharmacological or aromatic industries. Evidence is also gathered on the extreme adaptation of $C$. ladanifer to stressful conditions in the Mediterranean region, such as the ability to survive in low hydric and high solar exposition conditions, presistence in poor and contaminated soils, and growth inhibition of several other plants through the release of allelochemicals. Thus, the finding of potential applications for this plant may contribute to enhance the economic dimension of derelict lands, such as mine tailings or poor agricultural Mediterranean areas.

Keywords Rockrose $\cdot$ Labdanum $\cdot$ 2,2,6-Trimethylcyclohexanone $\cdot$ Taxonomy $\cdot$ Competitive traits

Fernanda Delgado

fdelgado@ipcb.pt

1 CBPBI, Centro de Biotecnologia de Plantas da Beira Interior, Quinta da Senhora de Mércules, Apartado 119, 6001-909 Castelo Branco, Portugal

2 Laboratoire Sols et Environnement (UMR

1120, INRA-Univ. Lorraine), ENSAIA,

2 Av. de la Forêt de Haye, TSA 4060254518 Vandoeuvre-lè

s-Nancy, France

3 IPCB-ESA, Escola Superior Agrária, Instituto Politécnico de Castelo Branco, Quinta da Senhora de Mércules, Apartado 119, 6001-909 Castelo Branco, Portugal

4 CERNAS/IPCB, Centro de Estudos de Recursos Naturais, Ambiente e Sociedade/Instituto Politécnico de Castelo Branco, Castelo Branco, Portugal

\section{Introduction}

Cistus ladanifer L. (Cistaceae), also known as rockrose, and called "esteva" (Portuguese) or "jara" (Spanish), is a resinous and fragrant evergreen shrub, very abundant among other wild species in the forest and uncultivated areas of the western Mediterranean region (Portugal, Spain, south of France, north of Morocco). This plant is frequently associated to negative impacts, such as agroecosystems occupation and competition, as well as fire promotion. Knowledge about the shrub's survival mechanisms may constitute a way either to fight and control it or to exploit it. Cistaceae plants have gained high biological interest, both at the level of rapid colonization of burnt and poor agricultural areas, as well as revegetation of metal-polluted sites, and at the level of phytotoxic and symbiotic interactions with the ecosystem, which consequently highlights its relevant aromatic and pharmacological potential applications (Dias et al. 2005; Martín-Pinto 
et al. 2006; Papaefthimiou et al. 2014; Santos et al. 2016). This shrub produces a resin, called labdanum, rich in valuable compounds, which have been extracted in countries such as France, Spain and Portugal, mainly to be used in the perfume industry due to its fixative and aromatic properties (Moyler and Clery 1997). In Spain, C. ladanifer labdanum has been exported to some Arabic countries, where it is used as incense (Papaefthimiou et al. 2014). Moreover, some labdanum compounds constitute an important alternative to ambergris, which is a rare ingredient obtained from a protected animal source (sperm whale), and provides starting materials for the manufacturing of synthetic ambers (Groom 1997). Essential oils are valuable products obtained from plants. Although in rockrose it has a low yield extraction of around $0.1 \%$, essential oil has a potential use in medical, cosmetic (Papaefthimiou et al. 2014) and food industry (Barrajón-Catalán et al. 2016).

Most of the current labdanum exploitation is based on wild $C$. ladanifer populations, although possibilities are emerging of cultivation this species on derelict land, such as low-productive agricultural fields or mine tailings (Santos et al. 2017). However, in order to develop C. ladanifer cultivation, knowledge on the ecology of the species, its reproductive biology, or inherent variability in secondary compounds is needed.

To fulfil this task, this study compiled and reviewed the existing scientific literature on C. ladanifer, focusing on its taxonomy, phylogeny, and phylogeography, its morphology and distribution, its reproductive biology and its chemical characterisation. The natural advantages of this species are also evidenced as competitive traits versus others species and/or as environmental responses.

\section{Taxonomy, phylogeny and phylogeography}

Cistaceae family comprises eight genera, five of which (Cistus, Fumana, Halimium, Helianthemum and Xolantha) are present in the Mediterranean area, and about 180 species. After several taxonomic re-evaluations, about twenty one species of Cistus are now recognized, spreading within white and pink-flowered lineages (Guzmán and Vargas 2005). These taxonomic changes have been mainly based on morphological characters. However, the type of pollen, specific genetic characteristics and chemical characterization of plants belonging to the genus Cistus have also been taken into account for taxonomy and phylogenetic divisions (Barrajón-Catalán et al. 2011). Ellul et al. (2002) reported significant differences in DNA content between pink-flowered species (subgenus Cistus) and white-flowered ones (subgenera Leucocistus and Halimioides).

Currently, twelve Cistus species are recognised in the Flora Iberica (Demoly and Montserrat 1993) distributed along three subgenera (Fig. 1). However, frequent hybridisations have been registered in the genus (Demoly and Montserrat 1993). Within C. ladanifer three subspecies are recognized (Fig. 1).

Morphological differences of Cistus genus have been clarified by the application of DNA sequencing and molecular markers, allowing a more complete taxonomic classification. In these studies, many authors used universal primers for non-coded regions of the chloroplast DNA since these are structurally stable, haploid and heritability is maternal (Fernández-Mazuecos and Vargas 2010; Guzmán and Vargas 2005, 2010; Hamilton 1999; Johnson and Soltis 1994; Taberlet et al. 1991). Sequencing of the Internal Transcribed Spacer region (Sun et al. 1994; White et al. 1990) from the nuclear genome has also been used at the level of Cistus genus, but showed to be less useful for species identification than plastid sequences. Apart from sequence analyses, nuclear markers such as RAPDs (Williams et al. 1990), AFLPs (Vos et al. 1995) and ISSRs (Zietkiewicz et al. 1994) and sets of primers for plastid microsatellites (Sebastiani et al. 2004; Weising and Gardner 1999) have been applied to the study of phylogeography and population genetics in C. ladanifer (Quintela-Sabarís et al. 2005, 2011, 2012) or in C. ladanifer. ssp. sulcatus, Halimium halimifolium and several other Cistus species from south of Portugal (Carlier et al. 2008).

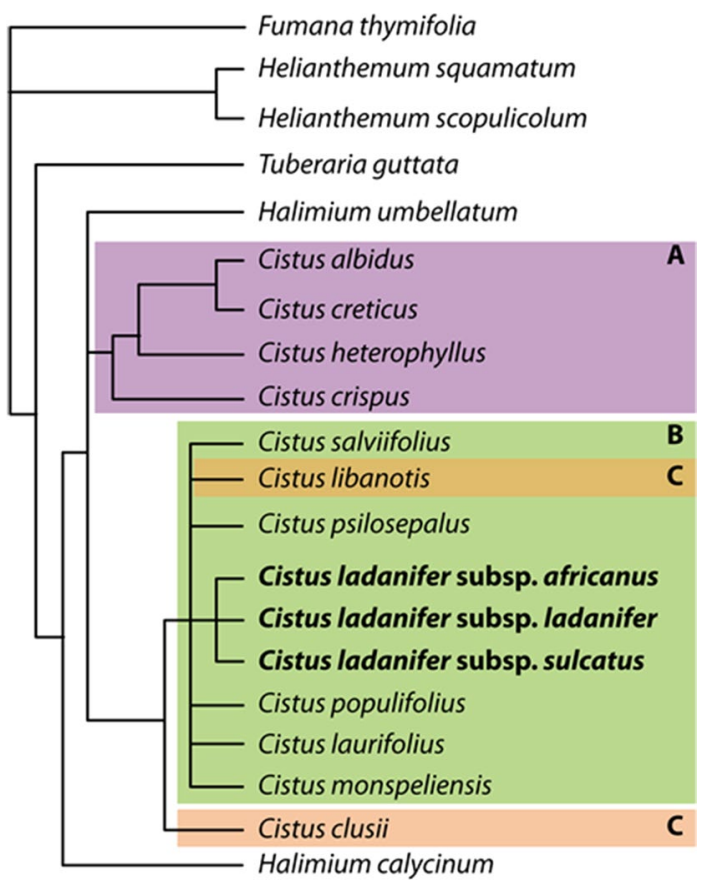

Fig. 1 Phylogenetic tree of Cistus species in Flora Iberica, where Asubgenus Cistus, B-subgenus Leucocistus, C-subgenus Halimioides (adapted from Guzmán and Vargas 2005). Cistus ladanifer and its subspecies are marked in bold type 
The taxonomic identity of $C$. ladanifer has been confirmed by Guzmán and Vargas (2005) on the basis of nuclear and plastid genetic sequence data. A later study done by Guzmán and Vargas (2009), using also nuclear and plastid DNA sequences, dated the origin of $C$. ladanifer and the divergence of its different subspecies in the Upper Pleistocene, well after the onset of the Mediterranean climate and the flooding of the Strait of Gibraltar. Therefore, the current species range in northern Africa and southwest Europe is the result of recent natural long distance dispersal events across that sea barrier (Guzmán and Vargas 2009). These data were further confirmed by Quintela-Sabarís et al. (2011) who, using chloroplast microsatellites (cpSSRs), identified three population lineages that resulted from isolation by geographic barriers (such as the Betic ranges or the Strait of Gibraltar) during glacial periods. Thus, the current distribution area of $C$. ladanifer is actually divided in three main genetically homogenous groups in (1) north of Africa, (2) Betic area (south and southeast of Iberian Peninsula) and (3) an extensive area from the southwest Iberian Peninsula to the south of France. Later analysis, using nuclear AFLP markers, confirmed the existence of those population lineages (Quintela-Sabarís et al. 2012).

Different genetic analyses suggest the more ancient origin of the subspecies africanus, and a subsequent differentiation for subspecies ladanifer and sulcatus (Guzmán and Vargas 2009; Quintela-Sabarís et al. 2011, 2012). Moreover, a study on C. ladanifer populations from the Algarve region (south of Portugal) with AFLPs and ISSRs uncovered significant genetic differentiation between subspecies ladanifer and sulcatus (Carlier et al. 2008). However, more recent analyses using cpSSRs and AFLPs (Quintela-Sabarís et al. 2011, 2012) showed no differentiation between subspecies ladanifer and sulcatus, and also indicated that Betic populations of C. ladanifer (identified as subspecies ladanifer on the basis of leaf morphology) formed an unusual cluster both at the chloroplast and nuclear level. Therefore, contrasting results between different studies, as well as the incongruence between morphology and genetic data pointed out the need for a taxonomic revision at the intraspecific level in these species.

\section{Morphology and distribution}

Cistus ladanifer is a perennial and woody shrub from the western Mediterranean area, from southern France to the north of Morocco and Algeria (Fig. 2). It appears over extensive xerophilic shrub lands, mainly in the southwestern region of the Iberian Peninsula, since sea level goes up to $1500 \mathrm{~m}$ (Demoly and Montserrat 1993). It may form very dense populations that mainly integrate poor siliceous and acidic soils with shale, granite or sandstone origin (Ribeiro and Delgado 2016). C. ladanifer is the major component of shrub lands in oligotrophic acid soils in the western half of the Iberian Peninsula (Rivas-Martínez 1979). However, distribution models support the idea of its tolerance to calcareous soils (Gaston and Fuller 2009) and subsp. sulcatus is even restricted to limestone-derived soils on coasts from southwestern Portugal (Demoly and Montserrat 1993). This
Fig. 2 Distribution of $C$. ladanifer in its native range, using georeferenced data from Global Biodiversity Information Facility-Cistus ladanifer L. in GBIF Secretariat (2017). GBIF Backbone Taxonomy. Checklist Dataset https://doi. org/10.15468/39omei accessed via GBIF.org on 2017-11-06. Inset presents the geographic context of $C$. ladanifer distribution area in southwestern Europe. Red square in the inset marks the area zoomed in the detail map

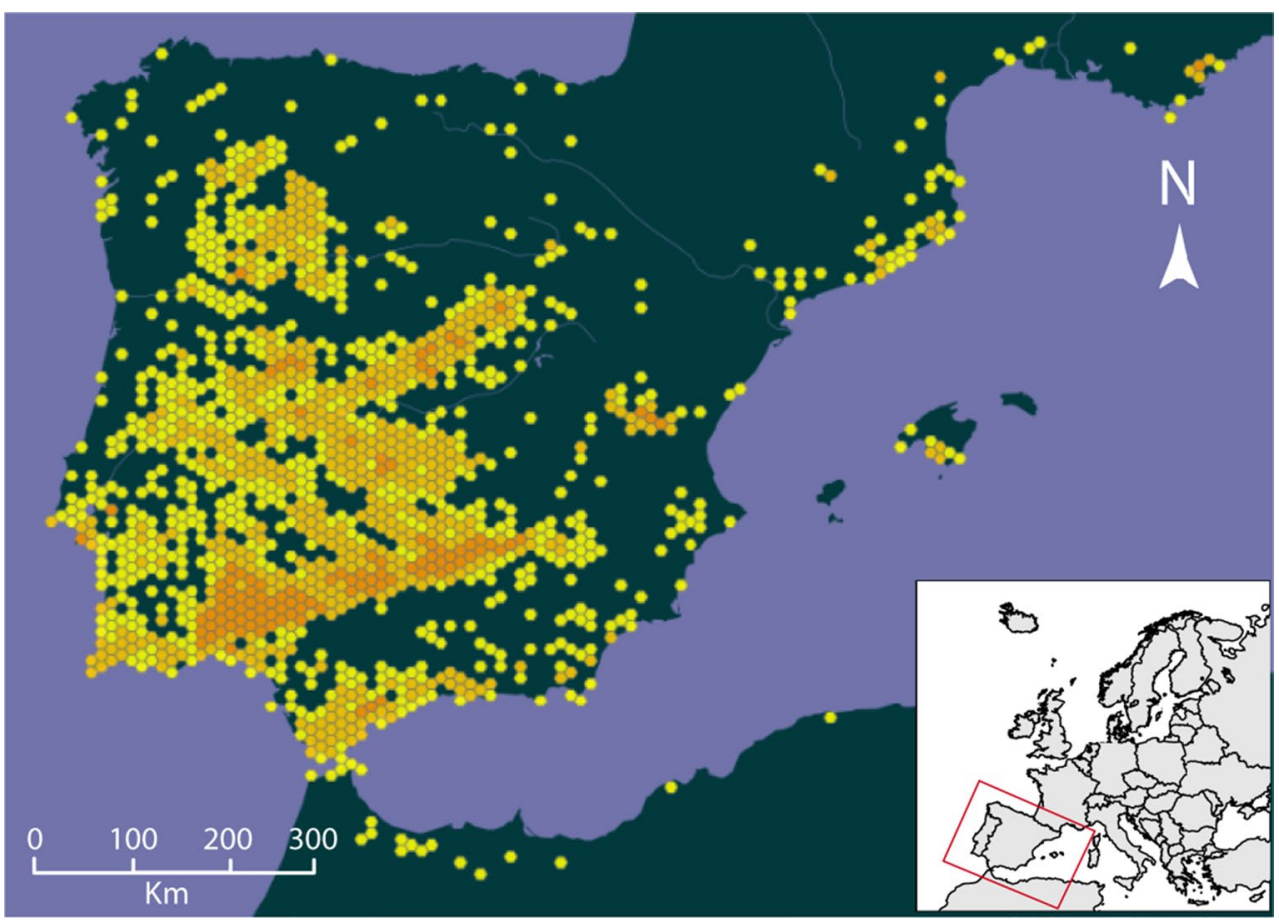


species behaves as colonizer on highly degraded areas (Alías et al. 2006; Pérez-García 1997; Valbuena et al. 1992) and has an increasing distribution as a result of human disturbance (Trabaud and Oustric 1989).

The subspecies ladanifer is primarily distributed in the Iberian Peninsula, northern Africa, southern France and isolated patches in the Canary Islands (being considered an introduced species in the two latter places); subspecies sulcatus is endemic to southwestern Portugal (Algarve region); and subspecies africanus is present in southern Spain (Cádiz, Málaga), but more commonly found in northern Africa (Demoly and Montserrat 1993).

An adult $C$. ladanifer plant may reach $2 \mathrm{~m}$ in height, with dense root and shoot systems (Bolaños and López 1949). It is a very viscous and erect shrub that has lanceolate green leaves with a glabrous upper surface and a back surface covered with a white tomentum. Leaves are presented in a decussate arrangement and welded at their base.

The morphology of leaves and capsule is used for the identification of its three recognized subspecies: africanus, ladanifer and sulcatus (Demoly and Montserrat 1993). Subspecies africanus has petiolate leaves, whereas those of subspecies ladanifer and sulcatus are sessile. Moreover, the subspecies africanus usually has lanceolate leaves with little apparent nerves and the capsule can be divided into 6-10 compartments. In subspecies ladanifer, the leaves have visible nerves and the capsule can be divided into 9-10 compartments. In subspecies sulcatus (originally described as Cistus palhinhae) the leaves, usually elliptic, are split by very visible nerves and the capsule can be divided into 8-9 compartments (Demoly and Montserrat 1993).

Overall C. ladanifer presents short peduncles $(5-16 \mathrm{~cm})$ covered by yellowish peltate hairs. Stigma is sessile and surrounded by a great number $(>100)$ of unequal stamens and the fruit is a loculicide capsule with 5-12 locules. The number of valves showed to be variable at the inter-populations, inter-individual, intra-individual and inter-annual levels (Narbona et al. 2010).

The exemplars of $C$. ladanifer present the largest and showiest flowers (5-10 cm in diameter) of genus Cistus and overall Spanish flora, constituted by three oval sepals with yellowish-green hairs and five petals. In these large and solitary flowers of subspecies ladanifer the five petals may be totally white (var. albiflorus) or have a red to maroon blotch at the base of each petal (var. maculatus) (Rouy and Foucaud 1895; Talavera et al. 1993). These varieties can occur separated in monomorphic populations or in mixed populations with both varieties present (Guzmán et al. 2011).

Apart from its big flowers and the high number of locules, another anatomic distinguishing trait of $C$. ladanifer is the production and exudation of a fragrant, sticky oleoresin, labdanum, comprising more than $10 \%(\mathrm{w} / \mathrm{w})$ of its dry weight (Demoly and Montserrat 1993; Dias et al. 2005; Gulz
1984; Mariotti et al. 1997; Vogt et al. 1987) or between 2 and $3.5 \%(\mathrm{w} / \mathrm{w})$ of its fresh weight (Lawrence 1999), from secretory trichomes found in leaves and photosynthetic stems (Chaves et al. 1997a; Masa et al. 2016a). According to Gulz et al. (1996), two kinds of trichomes are found in $C$. ladanifer leaves, the secretory ones, called glands, multicellular structures with the format of 20-30 $\mu \mathrm{m}$ short stalked small heads containing and secreting the labdanum, and the non-secretory ones, called hairs, unicellular stellate hairs with 6-20 branches. Hairs are only found, in a very dense arrangement, on the lower leaf surface (Gulz et al. 1996). Labdanum accumulates under the cuticle of the head cells of glands, which finally breaks due to pressure (Ascenção and Pais 1987; Borges 1987; Dias et al. 2005), resulting in total covering of leaf surface and glands completely soaked in it (Dias et al. 2005; Gulz et al. 1996). These secretory glands are also present in photosynthetic stems (Borges 1987, 1989), but it is not yet clear if they coexist with hairs at the lower leaves surface (Dias et al. 2005). Apart from the clear seasonal variation through the year, young leaves secrete greater amounts of labdanum than photosynthetic stems and these, in turn, secrete more than mature leaves (Masa et al. 2016a). Annually, labdanum production increases when minimum temperature increases (Dias et al. 2005) which means usually in the summer. According to Trabaud and Oustric (1989), labdanum production has a daily cycle too, in which it increases at noon. The role of labdanum is thought to be autoregulation and protection against herbivores and environmental stresses, such as low water and excessive UV light (Dias et al. 2005).

Like all other Cistus species, C. ladanifer is diploid $(2 n=18)$ (Demoly and Montserrat 1993) and its nuclear DNA content (2C) is $4.45 \pm 0.17 \mathrm{pg}$ (Ellul et al. 2002).

\section{Reproductive biology}

During spring, C. ladanifer produces a large number of ephemeral flowers (1-3 days). The flowering ends with the falling of petals and the refolding of sepals around the ovary tomentose. A flower that has not been fertilized will fall a few days after the end of the anthesis, its pedicel remaining on the plant (Guzmán et al. 2011).

Pollination in C. ladanifer is entomophyllous (mainly by individuals Diptera, Hymenoptera and Coleoptera). Flowers last for a few days and attract insects by nectar and high pollen production (more than 700,000 pollen grains per flower) (Talavera et al. 1993). Pollinators have been shown to exert a selection effect towards large flowers (Barrio and Teixido 2015). A gametophytic mechanism of incompatibility makes C. ladanifer an obligate outcrosser (Guzmán et al. 2015; Talavera et al. 1993). This feature, together with the short distances of pollen dispersal, results in reduced reproductive 
output in isolated plants, e.g. pollination success in isolated C. ladanifer plants dropped to zero when the distance to the nearest neighbour was around $33 \mathrm{~m}$ (Metcalfe and Kunin 2006).

Morphological diversity of white flowers (albiflorus or maculatus) showed no effect on $C$. ladanifer reproductive success, measured as flower production, fruit set or seed set (Guzmán et al. 2011). Moreover, weak reproductive barriers were found between floral morphs (Guzmán et al. 2015).

A single C. ladanifer capsule may contain around 1000 (from 318 to 1185) small $(1 \mathrm{~mm})$ polyhedral seeds and the total seed production by a single adult $C$. ladanifer plant may be up to 158,000 seeds each year (Bastida and Talavera 2002). Narbona et al. (2010) reported a positive relationship between number of valves and number of seeds per valve.

Seed release starts in the middle of summer and continues for 8-10 months. This dispersion is mainly barochorous, and more than $80 \%$ of seeds fall beneath the mother-plant canopy (Bastida and Talavera 2002). However, different granivorous ants of genus Goniomma and the red-deer (Cervus elaphus), which feed on seeds and fruits, respectively, may play an important role in seed dispersal over longer distances (Bastida and Talavera 2002; Malo and Suárez 1998). Cistaceae family is characterized to have "hardseededness" which is a specific type of physical dormancy (Thanos et al. 1992; Valbuena et al. 1992). C. ladanifer has small seeds with size between $0.5-1 \mathrm{~mm}$ and weight around $0.27 \mathrm{mg}$, which facilitates their accumulation and penetration in soils and leads to the formation of soil seed banks. These seed banks allow the escape from unfavorable conditions and guarantees propagation, for example, after a fire (Bastida and Talavera 2002; Talavera et al. 1993; Thanos et al. 1992). Hard seeds have a crusty and impermeable coat and, usually, germinate by thermal shock, smoke and nitrogenous salts treatments (Pérez-Fernández and Rodríguez-Echeverría 2003; PérezGarcía 1997). Cistus species are not exclusively dependent on fire however they have a slow germination without it (Delgado et al. 2001; Valbuena et al. 1992). The dry-heat pretreatment is one of the most effective methods increasing germination in the seeds of $C$. ladanifer (Valbuena et al. 1992). Interestingly, a small soft-coat fraction of seeds is also produced, which can soak water and, eventually, germinate (Alías et al. 2006; Pérez-García 1997; Thanos et al. 1992).

Cistus ladanifer seeds have considerable longevity as a result of the protection given by the impermeable coats (Thanos et al. 1992). Furthermore, the ability to produce seeds with different degrees of dormancy is, most probably, a mechanism by which $C$. ladanifer adapts to new environmental scenarios (Gutterman 1994; Kigel 1995). This peculiar two ways adaptation also contributes for seed characteristics variation in C. ladanifer (Delgado et al. 2001). Most germination happens in first year after fire, usually in autumn (first rains) but, in low rainfall years, hard seeds may germinate in the second or third year after production (Moreno et al. 2011; Quintana et al. 2004).

\section{Chemical characterization}

Apart from the classification based on morphological, anatomical and genetic characteristics, secondary metabolites can contribute to the taxonomic classification of plants (Demetzos and Dimas 2001). Although biotic and abiotic stimuli change the production level of some secondary metabolites (Alías et al. 2012; Papaefthimiou et al. 2014; Sangswan et al. 2011), the chemical profile or fingerprint depends on plants genotype.

Most studies about the chemical profile characterization of $C$. ladanifer, have mainly focused on its essential oil (cistus oil), restricting analysis to mono- and sesquiterpenes, the main constituents (Gomes et al. 2005; Greche et al. 2009; Mariotti et al. 1997; Robles et al. 2003). Other C. ladanifer extracts, usually called bioextracts, have also been studied, but to a lesser extent.

Labdanum, the exuded aromatic resin from C. ladani$\mathrm{fer}$, is economically important for countries like Spain and France (Papaefthimiou et al. 2014) and constitutes a specific kind of bioextract from intact plant material. It is traditionally obtained by boiling the plant material in water (Dias et al. 2005). However, other solvents have been applied either to plant material or resin, for analytical purposes of labdanum constituents: chloroform (Alías et al. 2012; Chaves et al. 1997a, 1998; Vogt et al. 1987), ethanol (Chaves et al. 1993), acetone (Wollenweber and Mann 1984), hexane (Pascual et al. 1982) and with water followed by organic solvents such as dichloromethane (Ramalho et al. 1999) and ethanol (Greche et al. 2009). Extraction with water has the advantage (over organic solvents) of being more ecologic and environmentally friendly (Barrajón-Catalán et al. 2011). Labdanum is characterized by its high content in diterpenes and flavonoids (Alías et al. 2012; Masa et al. 2016a), but it also contains mono- and sesquiterpenes. These later compounds are also markedly found in the oil obtained from distillation of labdanum (Oller-López et al. 2005; Weyerstahl et al. 1998).

Other bioextracts from C. ladanifer found in literature comprise extracts of milled plant samples with organic solvents (Barros et al. 2013; Guimarães et al. 2009 Santos et al. 2017) and water (Barrajón-Catalán et al. 2011; FernándezArroyo et al. 2010), supercritical $\mathrm{CO}_{2}$ extract (Rincón et al. 2000) and simultaneous distillation-solvent extract (Teixeira et al. 2007). Different types of extracts and different solvents result in different target chemical compounds extracted and analysed, thus it is often difficult to compare results between different studies. 
On the one hand, cistus and labdanum oils, as well as in the supercritical extract, have many identified mono- and sesquiterpenes and also co-distilled or co-extracted alkanes derived from waxes. On the other hand, many other non- or less volatile compounds have been identified in the exudate, such as diterpenes, flavonoids and phenolic compounds, apart from the mono- and sesquiterpenes (Fig. 3). Additionally, labdanum oil was found to have a significant constitution on diterpenes (Weyerstahl et al. 1998).

\section{Odoriferous compounds}

The most relevant volatile terpenes, according to the frequency of reports in the literature and their relative quantities in extracts, mainly labdanum and cistus oils, are listed in Table 1. C. ladanifer shows a different terpene profile from other Cistus species, with a close taxonomic relationship (Gulz 1984; Oller-López et al. 2005). Regarding mono- and sesquiterpenes, the most common reported major compounds are the monoterpenes $\alpha$-pinene (Gomes et al. 2005; Gulz 1984; Mariotti et al. 1997; Rincón et al. 2000; Robles et al. 2003; Teixeira et al. 2007; Vieira et al. 2017), camphene (Zidane et al. 2013) and pinocarveol (OllerLópez et al. 2005; Verdeguer et al. 2012) and the sesquiterpene viridiflorol (Gomes et al. 2005; Greche et al. 2009; Weyerstahl et al. 1998). In their literature review, Gomes et al. (2005) also observed that $\alpha$-pinene was the most commonly reported major compound. According to Robles et al. (2003), C. ladanifer var. maculatus produces more $\alpha$-pinene but less viridiflorol than var. albiflorus. However, Mariotti
Table 1 Most relevant low molecular weight terpenes found in $C$. ladanifer $\mathrm{L}$.

\begin{tabular}{lll}
\hline & Non-oxygenated & Oxygenated \\
\hline Monoterpenes & $\alpha$-Pinene & Pinocarveol \\
& $\beta$-Pinene & Pinocarvone \\
& Camphene & Myrtenol \\
& Limonene & Myrtenal \\
& p-Cymene & Verbenone \\
& & Borneol \\
& & Bornyl acetate \\
Sesquiterpenes & S-Cadinene & Terpinen-4-ol \\
& Aromadendrene & Ledol \\
Norisoprenes & - & $2,2,6$-Trimethylcyclohexanone \\
\hline
\end{tabular}

Extracts (Gomes et al. 2005; Greche et al. 2009; Gulz 1984; Mariotti et al. 1997; Oller-López et al. 2005; Ramalho et al. 1999; Rincón et al. 2000; Santos et al. 2017; Verdeguer et al. 2012; Vieira et al. 2017; Weyerstahl et al. 1998)

et al. (1997) and Santos et al. (2017) observed a quantitative variation of a similar chemical profile inside $C$. ladanifer populations not reported to be multivarietal.

Another important compound found in high proportions in $C$. ladanifer extracts is the carotenoid derivative norisoprene called 2,2,6-trimethylcyclohexanone (Gomes et al. 2005; Greche et al. 2009; Mariotti et al. 1997; Oller-López et al. 2005; Ramalho et al. 1999; Robles et al. 2003; Santos et al. 2017; Teixeira et al. 2007; Verdeguer et al. 2012; Weyerstahl et al. 1998; Zidane et al. 2013), which is one

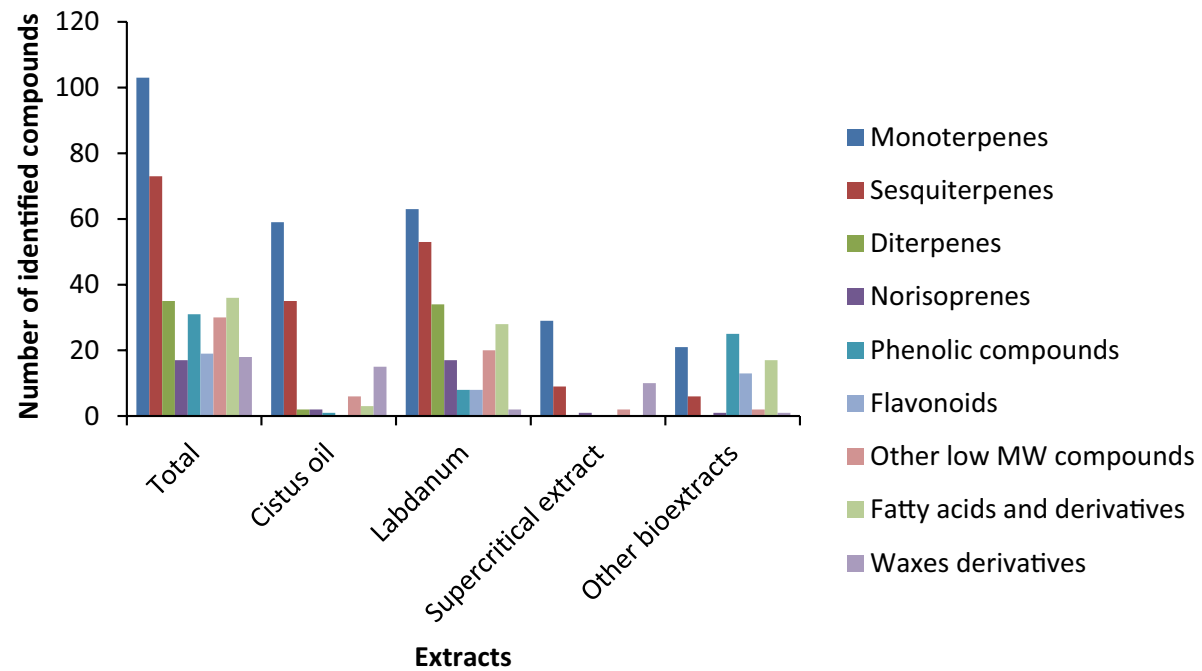

Fig. 3 Number of identified compounds in C. ladanifer extracts reported in literature: Alías et al. (2006, 2012); Barrajón-Catalán et al. (2011); Barros et al. (2013); Chaves et al. (1997a, b, 1998, 2001); Fernández-Arroyo et al. (2010); Guimarães et al. (2009); Gomes et al. (2005); Greche et al. (2009); Gulz (1984); Mariotti et al.
(1997); Oller-López et al. (2005); Pascual et al. (1982); Proksch and Gulz (1980a, b); Ramalho et al. (1999); Rincón et al. (2000); Robles et al. (2003); Santos et al. (2017); Sosa et al. (2004); Teixeira et al. (2007); Verdeguer et al. (2012); Vieira et al. (2017); Vogt et al. (1987); Weyerstahl et al. (1998); Wollenweber and Mann (1984) 
of the main compound responsible for $C$. ladanifer odour (Ramalho et al. 1999). This compound is not reported in other Cistus species, namely C. monspeliensis (Oller-López et al. 2005), C. laurifolius (Öğütveren and Tetik 2004), $C$. salvifolius (Demetzos et al. 2002), C. creticus (Paolini et al. 2009) and C. libanotis (Zidane et al. 2013). Thus, it may be a good chemotaxonomic marker at species level and even a C. ladanifer authenticity marker.

\section{Diterpenes}

Diterpenes are rarely reported in cistus and labdanum oil (Gomes et al. 2005; Mariotti et al. 1997; Oller-López et al. 2005; Weyerstahl et al. 1998) due to their low volatility. Rincón et al. (2000) did not report, also, diterpenes presence in their $\mathrm{CO}_{2}$ supercritical extracts. In contrast, labdanum is very rich in diterpenes mainly labdane-type ones (Alías et al. 2006, 2012; Greche et al. 2009; Pascual et al. 1982; Weyerstahl et al. 1998). According to Alías et al. (2006), the main diterpenes present in labdanum are 6-acetoxy-7oxo-8-labden-15-oic acid, 7-oxo-8-labden-15-oic acid and oxocativic acid. Besides these, Pascual et al. (1982) also identified 6,8(17)-labdadien-15-oic acid, labdanolic acid, 7-hydroxy-8(17)-labden-15-oic acid, 8-methoxy-labda15-oic acid and 8-hydroxy-13-labden-15-oic acid. Greche et al. (2009) obtained sclareol and 16-kaurene as the major diterpenes in their labdanum extract. Nor-diterpenes and a few diterpenes such as 16-kaurene, manoyl oxide and labdenols were reported to be present in labdanum oil (OllerLópez et al. 2005; Weyerstahl et al. 1998). Results from Gomes et al. (2005) demonstrate a quantitative variation of 15-nor-labdan-8-ol between essential oils of two different C. ladanifer populations from Alentejo, Portugal. Apart from this, to our knowledge, there is no study comparing the diterpene profiles of $C$. ladanifer subspecies and their varieties, as it had been done for the $C$. creticus subspecies (Anastasaki et al. 1999). Regarding environment effects on diterpenes production, Alías et al. (2012) observed that 6-acetoxy-7-oxo-8-labden-15-oic acid and 7-oxo-8-labden15-oic acid production is influenced by low temperature and low hydric stress and oxoativic acid diterpene production is only affected by temperature in the same way.

\section{Polyphenolic compounds and flavonoids}

Phenolic and other aromatic compounds accumulate as end-products from shikimate and acetate pathways and can range from relatively simple molecules (e.g. phenolic acids, flavonoids and benzenoids) to highly polymerised compounds (lignins, melanins and tannins) (Guimarães et al. 2010). Ellagitannins are reported to be the most significant compounds found in C. ladanifer leaves and stems (Barrajón-Catalán et al. 2010, 2011; Barros et al. 2013). However, according to Barrajón-Catalán et al. (2010) and Dentinho et al. (2007), they also exhibit high amounts of condensed tannins. Analysis of the chemical profile regarding polyphenolic compounds, such as hydrolysable tannins, shows a clear separation between the three Cistus subgenus: Cistus, Leucocistus and Halimioides. There is a clear separation between subgenus Cistus and subgenera Leucocistus and Halimioides and also between the latter, confirming previous evolutionary and phylogenetic studies (Barrajón-Catalán et al. 2011). Furthermore, the same authors also confirm the close taxonomic relationship between $C$. ladanifer and $C$. salvifolius within the subgenus Leucocistus due to their high concentration in ellagitannins.

Flavonoids aglycones are another major group of compounds present in the oleoresin exuded by the plant (Alías et al. 2012), represented by apigenin, kaempferol and their methylated derivatives, mainly 3-methyl-kaempferol and 3,7-dimethyl-kaempferol between others: 3,4'-dimethylkaempferol 3,7,4'-trimethyl-kaempferol, 4'- $O$-methylapigenin, 7-O-methyl-apigenin, 7,4'-di- $O$-methyl-apigenin (Chaves et al. 1997a, b, 1998; Sosa et al. 2004; Vogt et al. 1987; Wollenweber and Mann 1984). Secreted flavonoids aglycones (epicuticular) chemical patterns are usually complex and species specific. Thus, the application of lipophilic flavonoids patterns to systematic studies of Cistus seems more promising than that of uniform flavonoid glycosides (Dias et al. 2005; Vogt et al. 1987). C. ladanifer seems to exhibit differences in biosynthesis regulation between flavonoid glycosides and secreted flavonoid aglycones, since differences were found between flavonoid glycosides in vacuoles (quercetin, myrcetin and kaempferol) and secreted flavonoids (kaempferol and apigenin) (Gulz 1984). Only kaempferol derivatives, apigenin and apigenin derivatives appear in $C$. ladanifer as exuded flavonoids aglycones, while quercetin, myrcetin, luteolin and other flavonoid aglycones are present in other Cistus species (Vogt et al. 1987). Chaves et al. (1997b) observed different patterns of dimethylated kaempferols $\left(3,4^{\prime}\right.$ - or 3,7-dimethyl-kaempferol) secretion, but not of apigenins, coexisting in plants of a single population, which suggests the existence of different chemotypes, the 4'-methyltransferase activity being enhanced in the one and the 7-methyltransferase activity being enhanced in the other one. Exposure to high solar irradiance (UV) and hydric stress (drought), therefore in summer, are the most recognized phytochemical stresses, which increase flavonoid aglycones, specially methylated ones, as well as labdanum production and secretion (Chaves et al. 1993, 1997a; Vogt et al. 1987). 


\section{Competitive traits}

In the Mediterranean region, $C$. ladanifer plays a fundamental role in the occupation of habitats and interactions with the ecosystem (Águeda et al. 2008; Guzmán et al. 2011; Hernández-Rodríguez et al. 2013), establishing symbiotic relationships with some microorganisms (Comandini et al. 2006; Fogel and Trappe 1978; MartínPinto et al. 2006; Mediavilla et al. 2016).

Cistus ladanifer populations also constitute early succession stages adapted to disturbances operating in Mediterranean ecosystems, especially fire, as they are extremely resistant to changes in the physical, chemical and biochemical properties of soils, as water and light stress. It develops dense shallow root systems that favour water uptake in transient wet periods (Bolaños and López 1949). In addition, it is semi-deciduous, retaining small-sized potentially active leaves through the summer drought (Nunez-Olivera et al. 1996). Their ability to develop in nutrient-poor areas may have been favoured by the establishment of symbioses with microorganisms in roots. Several bacteria strains have been isolated from $C$. ladanifer roots, some with a capacity of phosphate solubilisation or siderophore production (one of them identified as Plant Growth Promoting Rhizobacteria-PGPR) (Carro et al. 2017; Díez-Méndez et al. 2017; Solano et al. 2007).

Some authors suggest that in young leaves lacking epidermis, trichomes and their exudates may serve as a functional analogue of the epidermis in mature leaves (Masa et al. 2016a, b). They play a protective role against phytopathogenic fungi, herbivores and UV radiation (Sosa et al. 2004; Masa et al. 2016b). Due to its content in flavonoids and other phenolic compounds, the secretion of labdanum has several beneficial effects for $C$. ladanifer plants, such as the photoprotective role on leaves, especially in summer when exudation increases (Chaves et al. 1993) and the defence against herbivores eating C. ladanifer leaves through impairment of mouth skeletal muscle relaxation (Sosa et al. 2004).

Phenols, terpenes, alkaloids and other secondary metabolites showing phytotoxic activity can reduce the growing of other plants, a mechanism known as allelopathy (Agra-Coelho et al. 1980; Chaves et al. 2001; Dias 2001; Dias et al. 2005; Herranz et al. 2006; Malato-Beliz et al. 1992; Verdeguer et al. 2012). It is thought that this effect is caused by competition for nutrients, moisture, chemical interference, foliage accumulation, and light penetration (Aerts et al. 1991; Chaves and Escudero 1997; Friedman 1995; Kuuluvainen 1994; Muller and Muller 1956). In parallel, auto-toxicity was demonstrated in $C$. ladanifer and it may be involved in the control of the species itself (Alías et al. 2006; Herranz et al. 2006; Manzano et al. 2005).
Studies about synthesis of secondary metabolites demonstrated that the intra-population variability may be conditioned by environmental and/or individual factors. Spacial arrangement of $C$. ladanifer populations may occur and this may be a strategy to save energy, while preserving the response capacity and protection against externals factors. This will be a clear advantage over other species, providing good possibilities to adapt to variable environmental effects and increasing survival (Masa et al. 2016b). This trait may explain the quantitative variation of the chemical profile found by many authors within a $C$. ladanifer population as stated before.

Regarding its relation to soils, C. ladanifer is a pseudometallophyte, meaning that it has populations on both normal and metalliferous (metal rich) substrates (Pollard et al. 2002). More precisely, subspecies ladanifer and africanus have successfully colonised and established populations on serpentine areas and on mine tailings, where in some cases they have become the dominant species (Alvarenga et al. 2004; Ater et al. 2000; Lázaro et al. 2006; QuintelaSabarís 2012). The colonisation of metalliferous substrates by plants is accompanied by micro evolutionary processes leading in most cases to the formation of metal-tolerant ecotypes (Linhart and Grant 1996). Tolerant plants are thus able to develop on metal-rich soils, toxic for most other plants (Antonovics 1975; Macnair 1993) by the development of mechanisms for efficient control of metal fluxes inside and through the plant (Hall 2002). It has been proposed that tolerance to metals may be a widespread trait in C. ladanifer, on the basis of two evidences: (1) the multiple origin of metallicolous populations of $C$. ladanifer, with no genetic imprints (such as genetic bottlenecks or founder effects) related to soil type on chloroplast or nuclear markers (Quintela-Sabarís et al. 2010, 2012), (2) no differences between metallicolous and non-metallicolous populations in growth response to treatments with $\mathrm{Co}, \mathrm{Ni}$ and $\mathrm{Zn}$ under hydroponic conditions (Quintela-Sabarís 2012). However, further studies are needed to determine if this apparent tolerance is based on plant mechanisms or whether it is mediated by metal-tolerant ectomycorrhizal fungi as advocated by Colpaert et al. (2011).

\section{Conclusion}

Apart from clear morphological differences, molecular data support the entity of $C$. ladanifer as a true species, although the unresolved incongruence between phylogeographic data and the morphological subspecies deserves the development of new research on this topic. C. ladanifer also has a specific composition of its fragrant exudate, carotenoid derivative norisoprene 2,2,6-trimethylcyclohexanone having been proposed as an authenticity marker in case of using this species 
for pharmacological or aromatic industries. Furthermore, in what regards chemical composition, $C$. ladanifer seems to show some variation at subspecies, varieties and even populations and at the individual level, which shows the need for research and selection of better subspecies, varieties and ecotypes in accordance to specific applications. Finally, evidence was given for the extreme adaptation of C. ladanifer to stressful conditions in Mediterranean region, such as the ability to survive in low hydric and high solar exposition conditions, presistence in poor and contaminated soils and growth inhibition of several other plants through the release of allelochemicals. Thus, finding new potential applications for this plant may contribute to enhance the economic dimension of derelict lands, such as mine tailings or poor agricultural Mediterranean areas.

Author contribution statement JRR, CQS and FD worked on taxonomy, phylogeny and phylogeography section. DFF, JRR, CQS and FD worked on morphology and distribution section. JLD, CQS and FD worked on reproductive biology section. DFF worked on chemical characterization section. DFF, JRR, JLD and CQS worked on competitive traits section. DFF, JRR, JLD, CQS and FD gathered the information and wrote and edited the manuscript. JCG promoted, revised and approved the work.

\section{References}

Aerts RJ, Snoeijer W, Meijden E, Verpoorte R (1991) Allelopathic inhibition of seed germination by Cinchona alkaloids? Phytochemistry 30(9):2947-2951. https://doi.org/10.1016/ S0031-9422(00)98229-3

Agra-Coelho C, Rosa ML, Moreira I (1980) Efeitos alelopáticos de Cistus ladanifer L. In: III Simpósio nacional de herbologia, pp 165-178

Águeda B, Parladé J, Fernández-Toirán LM, Cisneros Ó, Miguel AM, Modrego MP, Martínez-Peña F, Pera J (2008) Mycorrhizal synthesis between Boletus edulis species complex and rockroses (Cistus sp.). Mycorrhiza 18(8):443-449. https://doi.org/10.1007/ s00572-008-0192-3

Alías JC, Sosa T, Escudero JC, Chaves N (2006) Autotoxicity against germination and seedling emergence in Cistus ladanifer L. Plant Soil 282(1-2):327-332. https://doi.org/10.1007/ s11104-005-6066-y

Alías JC, Sosa T, Valares C, Escudero JC, Chaves N (2012) Seasonal variation of Cistus ladanifer L. diterpenes. Plants 1(1):6-15. https://doi.org/10.3390/plants1010006

Alvarenga PM, Araújo MF, Silva JAL (2004) Elemental uptake and root-leaves transfer in Cistus Ladanifer L. growing in a contaminated pyrite mining area (Aljustrel-Portugal). Water Air Soil Pollut 152(1-4):81-96. https://doi.org/10.1023/B:WATE.0000 $015333.24165 .5 \mathrm{e}$

Anastasaki T, Demetzos C, Perdetzoglou D, Gazouli M, Loukis A, Harvala C (1999) Analysis of labdane-type diterpenes from Cistus creticus (subsp. creticus and subsp. eriocephalus), by GC and GC-MS. Planta Med 65(8):735-739. https://doi. org/10.1055/s-1999-14095

Antonovics J (1975) Metal tolerance in plants: perfecting an evolutionary paradigm. In: Con PLL (ed) Heavy metals in the environment. University of Toronto, Toronto, pp 169-186

Ascenção L, Pais MSS (1987) Morfologia e ocorréncia de tricomas glandulares em C. ladanifer L. 2as Jornadas nacionais de plantas aromáticas e óleos essenciais, Lisbon, p 197

Ater M, Lefèbvre C, Gruber W, Meerts P (2000) A phytogeochemical survey of the flora of ultramafic and adjacent normal soils in north Morocco. Plant Soil 218(1-2):127-135. https://doi.org/ 10.1023/A:1014925007960

Barrajón-Catalán E, Fernández-Arroyo S, Saura D, Guillén E, Fernández-Gutiérrez A, Segura-Carretero A, Micol V (2010) Cistaceae aqueous extracts containing ellagitannins show antioxidant and antimicrobial capacity, and cytotoxic activity against human cancer cells. Food Chem Toxicol 48(8-9):22732282. https://doi.org/10.1016/j.fct.2010.05.060

Barrajón-Catalán E, Fernández-Arroyo S, Roldán C, Guillén E, Saura D, Segura-Carretero A, Micol V (2011) A systematic study of the polyphenolic composition of aqueous extracts deriving from several Cistus genus species: evolutionary relationship. Phytochem Anal 22(4):303-312. https://doi. org/10.1002/pca.1281

Barrajón-Catalán E, Tomás-Menor L, Morales-Soto A, Martí N, Saura D, Carretero AS, Micol V (2016) Rockroses (Cistus sp.) oils. In: Preedy VE (ed) Essential oils in food preservation, flavor and safety. Elsevier Inc., Amsterdam, pp 649-658

Barrio M, Teixido AL (2015) Sex-dependent selection on flower size in a large-flowered Mediterranean species: an experimental approach with Cistus ladanifer. Plant Syst Evol 301(1):113124. https://doi.org/10.1007/s00606-014-1058-0

Barros L, Dueñas M, Alves CT, Silva S, Henriques M, SantosBuelga C, Ferreira ICFR (2013) Antifungal activity and detailed chemical characterization of Cistus ladanifer phenolic extracts. Ind Crop Prod 41:41-45. https://doi.org/10.1016/j. indcrop.2012.03.038

Bastida F, Talavera S (2002) Temporal and spatial patterns of seed dispersal in two Cistus species (Cistaceae). Ann Bot 89(4):427-434 PMID: 12096803

Bolaños MM, López EG (1949) Jarales y jaras (Cistografía hispánica). Ediciones Ares, Madrid

Borges AEL (1987) Aspectos morfológicos dos tricomas do $C$. ladanifer L. (Cistaceae). 2as. Jornadas nacionais de plantas aromáticas e óleos essenciais, Lisbon, pp 75-80

Borges AEL (1989) Contribuição para o estudo da anatomia da folha e caule de $C$. ladanifer L. Jornadas ibericas de plantas médicinales aromáticas y de aceites esenciales, Madrid

Carlier J, Leitão JOS, Fonseca F (2008) Population genetic structure of Cistus ladanifer L. (Cistaceae) and genetic differentiation from co-occurring Cistus species. Plant Spec Biol 23(3):141151. https://doi.org/10.1111/j.1442-1984.2008.00220.x

Carro L, Mulas R, Pastor-Bueis R, Blanco D, Terrón A, GonzálezAndrés F, Peix A, Velázquez E (2017) Delftia rhizosphaerae sp. nov. isolated from the rhizosphere of Cistus ladanifer. Int J Syst Evol Microbiol 67(6):1957-1960. https://doi.org/10.1099/ ijsem.0.001892

Chaves N, Escudero JC (1997) Allelopathic effect of Cistus ladanifer on seed germination. Funct Ecol 11(4):432-440. https://doi. org/10.1046/j.1365-2435.1997.00107.x

Chaves N, Ríos JJ, Gutierrez C, Escudero JC, Olías JM (1998) Analysis of secreted flavonoids of Cistus ladanifer L. by high-performance liquid chromatography-particle beam mass spectrometry. J Chromatogr A 799(1-2):111-115. https://doi. org/10.1016/S0021-9673(97)01042-X 
Chaves N, Escudero JC, Gutiérrez-Merino C (1993) Seasonal variation of exudate of Cistus ladanifer. J Chem Ecol 19(11):2577-2591 PMID: 24248712

Chaves N, Escudero JC, Gutierrez-Merino C (1997a) Role of ecological variables in the seasonal variation of flavonoid content of Cistus ladanifer exudate. J Chem Ecol 23(3):579-603. https:// doi.org/10.1023/B:JOEC.0000006398.79306.09

Chaves N, Escudero JC, Gutiérrez-Merino C (1997b) Quantitative variation of flavonoids among individuals of a Cistus ladanifer population. Biochem Syst Ecol 25(5):429-435. https://doi. org/10.1016/S0305-1978(97)00019-7

Chaves N, Sosa T, Alías JC, Escudero JC (2001) Identification and effects of interaction phytotoxic compounds from exudate of $\mathrm{Cis}$ tus ladanifer leaves. J Chem Ecol 27(3):611-621. https://doi.org /10.1023/A:1010336921853

Colpaert JV, Wevers JHL, Krznaric E, Adriaensen K (2011) How metal-tolerant ecotypes of ectomycorrhizal fungi protect plants from heavy metal pollution. Ann For Sci 68(1):17-24. https:// doi.org/10.1007/s13595-010-0003-9

Comandini O, Contu M, Rinaldi AC (2006) An overview of Cistus ectomycorrhizal fungi. Mycorrhiza 16(6):381-395. https://doi. org/10.1007/s00572-006-0047-8

Delgado JA, Serrano JM, López F, Acosta FJ (2001) Heat shock, massdependent germination, and seed yield as related components of fitness in Cistus ladanifer. Environ Exp Bot 46(1):11-20. https:// doi.org/10.1016/S0098-8472(01)00076-4

Demetzos C, Dimas KS (2001) Labdane-type diterpenes: chemistry and biological activity. Stud Nat Prod Chem 25:235-292. https:// doi.org/10.1016/S1572-5995(01)80009-0

Demetzos C, Angelopoulou D, Perdetzoglou D (2002) A comparative study of the essential oils of Cistus salvifolios in several populations of Crete (Greece). Biochem Syst Ecol 30(7):651-665. https://doi.org/10.1016/S0305-1978(01)00145-4

Demoly JP, Montserrat P (1993) Cistus. In: Castroviejo S (ed) Flora Ibérica. CSIC (Centro Superior Investigaciones Científica), Madrid, pp 319-337

Dentinho MTP, Moreira OC, Pereira MS, Bessa RJB (2007) The use of a tannin crude extract from Cistus ladanifer $\mathrm{L}$. to protect soyabean protein from degradation in the rumen. Animal 1(5):645650. https://doi.org/10.1017/S1751731107689745

Dias LS (2001) Describing phytotoxic effects on cumulative germination. J Chem Ecol 27(2):411-418. https://doi.org/10.102 3/A:1005644808956

Dias AS, Costa CT, Dias LS (2005) Allelopathic plants. XVII. Cistus ladanifer L. Allelopathy J 16(1):1-15

Díez-Méndez A, Rivas R, Mateos PF, Martínez-Molina E, Santín PJ, Sánchez-Rodríguez JA, Velázquez E (2017) Bacillus terrae sp. nov. isolated from Cistus ladanifer rhizosphere soil. Int J Syst Evol Microbiol 67:1478-1481. https://doi.org/10.1099/ ijsem.0.001742

Ellul P, Boscaiu M, Vicente O, Moreno V, Rosselló JA (2002) Intraand interspecific variation in DNA content in Cistus (Cistaceae). Ann Bot 90(3):345-351. https://doi.org/10.1093/aob/mcf194

Fernández-Arroyo S, Barrajón-Catalán E, Micol V, Segura-Carretero A, Fernández-Gutiérrez A (2010) High-performance liquid chromatography with diode array detection coupled to electrospray time-of-flight and ion-trap tandem mass spectrometry to identify phenolic compounds from a Cistus ladanifer aqueous extract. Phytochem Anal 21(4):307-313. https://doi.org/10.1002/ pca. 1200

Fernández-Mazuecos M, Vargas P (2010) Ecological rather than geographical isolation dominates quaternary formation of Mediterranean Cistus species. Mol Ecol 19(7):1381-1395. https://doi. org/10.1111/j.1365-294X.2010.04549.x

Fogel R, Trappe JM (1978) Fungus consumption (mycophagy) by small animals. Northwest Sci 52(1):1-31
Friedman J (1995) Allelopathy, autotoxicity, and germination. In: Kigel J, Galili G (eds) Seed development and germination. Marcel Dekker, New York, pp 599-628

Gaston KJ, Fuller RA (2009) The sizes of species geographic ranges. J Appl Ecol 46(1):1-9. https://doi. org/10.1111/j.1365-2664.2008.01596.x

Gomes PB, Mata VG, Rodrigues AE (2005) Characterization of the portuguese-grown Cistus ladanifer essential oil. J Essent Oil Res 17(2):160-165. https://doi.org/10.1080/10412905.2005.9698864

Greche H, Mrabet N, Zrira S, Ismaïli-Alaoui M, Benjilali B, Boukir A (2009) The volatiles of the leaf oil of Cistus ladanifer L. var. albiflorus and labdanum extracts of moroccan origin and their antimicrobial activities. J Essent Oil Res 21(2):166-173. https:// doi.org/10.1080/10412905.2009.9700140

Groom N (1997) The new perfume handbook. Blackie Academic and Professional, London

Guimarães R, Barros L, Carvalho AM, Sousa MJ, Morais JS, Ferreira ICFR (2009) Aromatic plants as a source of important phytochemicals: vitamins, sugars and fatty acids in Cistus ladanifer, Cupressus lusitanica and Eucalyptus gunnii leaves. Ind Crop Prod 30(3):427-430. https://doi.org/10.1016/j. indcrop.2009.08.002

Guimarães R, Sousa MJ, Ferreira ICFR (2010) Contribution of essential oils and phenolics to the antioxidant properties of aromatic plants. Ind Crop Prod 32(2):152-156. https://doi.org/10.1016/j. indcrop.2010.04.011

Gulz PG (1984) The composition of terpene hydrocarbons in the essential oils from leaves of four Cistus species. Z Naturforsch 39(7-8):699-704. https://doi.org/10.1515/znc-1984-7-802

Gulz PG, Herrmann T, Hangst K (1996) Leaf trichomes in the genus Cistus. Flora 191(1):85-104. https://doi.org/10.1016/ S0367-2530(17)30692-8

Gutterman Y (1994) Strategies of seed dispersal and germination in plants inhabiting deserts. Bot Rev 60:373-425. https://doi. org/10.1007/BF02857924

Guzmán B, Vargas P (2005) Systematics, character evolution, and biogeography of Cistus L. (Cistaceae) based on ITS, trnL-trnF, and matK sequences. Mol Phylogenet Evol 37(3):644-660. https:// doi.org/10.1016/j.ympev.2005.04.026

Guzmán B, Vargas P (2009) Long-distance colonization of the western Mediterranean by Cistus ladanifer (Cistaceae) despite the absence of special dispersal mechanisms. J Biogeogr 36(5):954 968. https://doi.org/10.1111/j.1365-2699.2008.02040.x

Guzmán B, Vargas P (2010) Unexpected synchronous differentiation in Mediterranean and Canarian Cistus (Cistaceae). Perspect Plant Ecol 12(3):163-174. https://doi.org/10.1016/j.ppees.2009.09.002

Guzmán B, Narbona E, Vargas P (2011) Similar reproductive success of the two petal colour polymorphisms of Cistus ladanifer (Cistaceae). Plant Biosyst 145(4):931-937. https://doi.org/10.1080/11 263504.2011.633111

Guzmán B, Narbona E, Vargas P (2015) Investigating reproductive incompatibility barriers in a Mediterranean rockrose (Cistus ladanifer). Plant Biosyst 149(1):1-6. https://doi.org/10.1080/1 1263504.2013.801369

Hall JL (2002) Cellular mechanisms for heavy metal detoxification and tolerance. J Exp Bot 53(3):1-11. https://doi.org/10.1016/j. ppees.2009.09.002

Hamilton MB (1999) Four primer pairs for the amplification of chloroplast intergenic regions with intraspecific variation. Mol Ecol 8:521-523 PMID: 10199016

Hernández-Rodríguez M, Oria-de-Rueda JA, Martín-Pinto P (2013) Post-fire fungal succession in a Mediterranean ecosystem dominated by Cistus ladanifer L. For Ecol Manag 289:48-57. https:// doi.org/10.1016/j.foreco.2012.10.009

Herranz JM, Ferrandis P, Copete MA, Duro EM, Zalacaín A (2006) Effect of allelopathic compounds produced by Cistus ladanifer 
on germination of 20 Mediterranean taxa. Plant Ecol 184(2):259272. https://doi.org/10.1007/s11258-005-9071-6

Johnson LA, Soltis DE (1994) matK DNA sequences and phylogenetic reconstruction in Saxifragaceae s. str. Syst Bot 19(1):143-156. https://doi.org/10.2307/2419718

Kigel J (1995) Seed germination in arid and semi-arid regions. In: Kigel J, Galili G (eds) Seed development and germination. Marcel Dekker, New York, pp 645-699

Kuuluvainen T (1994) Gap disturbance, ground microtopography, and the regeneration dynamics of boreal coniferous forests in Finland: a review. Ann Zool Fenn 31(1):35-51

Lawrence BM (1999) Progress in essential oils. Perfum Flavor 24(4):31-50

Lázaro JD, Kidd PS, Martínez CM (2006) A phytogeochemical study of the Trás-os-Montes region (NE Portugal): possible species for plant-based soil remediation technologies. Sci Total Environ 354(2-3):265-277. https://doi.org/10.1016/j. scitotenv.2005.01.001

Linhart YB, Grant MC (1996) Evolutionary significance of local genetic differentiation in plants. Annu Rev Ecol Syst 27:237277. https://doi.org/10.1146/annurev.ecolsys.27.1.237

Macnair MR (1993) The genetics of metal tolerance in vascular plants. N Phytol 124(4):541-559. https://doi. org/10.1111/j.1469-8137.1993.tb03846.x

Malato-Beliz J, Escudero JC, Buyolo T (1992) Application of traditional indices and of diversity to an ecotonal area of different biocoenes. The state of the art in vegetation science. International Association for Vegetation Science, Toledo

Malo JE, Suárez F (1998) The dispersal of a dry-fruited shrub by red deer in a Mediterranean ecosystem. Ecography 21(2):204-211. https://doi.org/10.1111/j.1600-0587.1998.tb00673.x

Manzano P, Malo JE, Peco B (2005) Sheep gut passage and survival of Mediterranean shrub seeds. Seed Sci Res 15(1):21-28. https:// doi.org/10.1079/SSR2004192

Mariotti JP, Tomi F, Casanova J, Costa J, Bernardini AF (1997) Composition of the essential oil of Cistus ladaniferus $\mathrm{L}$. cultivated in Corsica (France). Flavour Frag J 12:147-151

Martín-Pinto P, Vaquerizo H, Peñalver F, Olaizola J, Oria-de-Rueda JA (2006) Early effects of a wildfire on the diversity and production of fungal communities in Mediterranean vegetation types dominated by Cistus ladanifer and Pinus pinaster in Spain. Forest Ecol Manag 225(1-3):296-305. https://doi.org/10.1016/j. foreco.2006.01.006

Masa CV, Díaz TS, Gallego JCA, Lobón NC (2016a) Quantitative variation of flavonoids and diterpenes in leaves and stems of Cistus ladanifer $\mathrm{L}$. at different ages. Molecules 21(3):275. https://doi. org/10.3390/molecules21030275

Masa CV, Gallego JCA, Lobón NC, Díaz TS (2016b) Intra-population variation of secondary metabolites in Cistus ladanifer L. Molecules 21(7):1-12. https://doi.org/10.3390/molecules21070945

Mediavilla O, Olaizola J, Santos-del-Blanco L, Oria-de-Rueda JA, Martín-Pinto P (2016) Mycorrhization between Cistus ladanifer L. and Boletus edulis Bull. is enhanced by the mycorrhiza helper bacteria Pseudomonas fluorescens Migula. Mycorrhiza 26(2):161-168. https://doi.org/10.1007/s00572-015-0657-0

Metcalfe DB, Kunin WE (2006) The effects of plant density upon pollination success, reproductive effort and fruit parasitism in Cistus ladanifer L. (Cistaceae). Plant Ecol 185:41. https://doi. org/10.1007/s11258-005-9082-3

Moreno JM, Zuazua E, Pérez B, Luna B, Velasco A, Dios VRd (2011) Rainfall patterns after fire differentially affect the recruitment of three Mediterranean shrubs. Biogeosciences 8:3721-3732. https://doi.org/10.5194/bg-8-3721-2011

Moyler DA, Clery RA (1997) The aromatic resins: their chemistry and uses. In: Swift KAD (ed) Flavours and fragrances. Royal Society of Chemistry, Great Britain, pp 96-115
Muller WH, Muller CH (1956) Association patterns involving desert plants that contain toxic products. Am J Bot 43(5):354-361

Narbona E, Guzmán B, Arroyo J, Vargas P (2010) Why are fruit traits of Cistus ladanifer (Cistaceae) so variable: a multi-level study across the western Mediterranean region. Perspect Plant Ecol 12(4):305-315. https://doi.org/10.1016/j.ppees.2010.06.001

Nunez-Olivera E, Martinez-Abaigar J, Escudero JC (1996) Adaptability of leaves of Cistus ladanifer to widely varying environmental conditions. Funct Ecol 10(5):636-646. https://doi. org/10.2307/2390174

Öğütveren M, Tetik SS (2004) Composition of the essential oil of Cistus laurifolius L. from Turkey. J Essent Oil Res 16(1):2425. https://doi.org/10.1080/10412905.2004.9698641

Oller-López JL, Rodríguez R, Cuerva JM, Oltra JE, Bazdi B, Dahdouh A, Lamarti A, Mansour AI (2005) Composition of the essential oils of Cistus ladaniferus and C. monspeliensis from Morocco. J Essent Oil Res 17(5):553-555. https://doi.org/10. 1080/10412905.2005.9698992

Paolini J, Falchi A, Quilichini Y, Desjobert J-M, Cian M-CD, Varesi L, Costa J (2009) Morphological, chemical and genetic differentiation of two subspecies of Cistus creticus L. (C. creticus subsp. eriocephalus and $C$. creticus subsp. corsicus). Phytochemistry 70(9):1146-1160. https://doi.org/10.1016/j. phytochem.2009.06.013

Papaefthimiou D, Papanikolaou A, Falara V, Givanoudi S, Kostas S, Kanellis AK (2014) Genus Cistus: a model for exploring labdane-type diterpenes' biosynthesis and a natural source of high value products with biological, aromatic, and pharmacological properties. Front Chem 2:35. https://doi.org/10.3389/ fchem.2014.00035

Pascual JTD, Bellido IS, Basabe P, Marcos IS, Ruano LF, Urones JG (1982) Labdane diterpenoids from Cistus ladaniferus. Phytochemistry 21(4):899-901. https://doi. org/10.1016/0031-9422(82)80089-7

Pérez-Fernández MA, Rodríguez-Echeverría S (2003) Effect of smoke, charred wood, and nitrogenous compounds on seed germination of ten species from woodland in central-western Spain. J Chem Ecol 29:237-251. https://doi.org/10.102 3/A:1021997118146

Pérez-García F (1997) Germination of Cistus ladanifer seeds in relation to parent material. Plant Ecol 133(1):57-62. https://doi.org/10. 1023/A:1009776910683

Pollard AJ, Powell KD, Harper FA, Smith JAC (2002) The genetic basis of metal hyperaccumulation in plants. Crit Rev Plant Sci 21(6):539-566. https://doi.org/10.1080/0735-260291044359

Proksch P, Gulz P (1980a) Phenylpropanolic acid esters in the essential oil of Cistus ladanifer L. (Cistaceae). Z Naturforsch 35(34):201-203. https://doi.org/10.1515/znc-1980-3-405

Proksch P, Gulz P (1980b) Further oxygenated compounds in the essential oils of Cistus ladanifer L. (Cistaceae). Z Naturforsch 35(7-8):529-532. https://doi.org/10.1515/znc-1980-7-801

Quintana JR, Cruz A, Fernández-González F, Moreno JM (2004) Time of germination and establishment success after fire of three obligate seeders in a Mediterranean shrubland of central Spain. J Biogeogr 31:241-249. https://doi. org/10.1111/j.1365-2699.2004.00955.x

Quintela-Sabarís C (2012) Evolutionary origin and ecophysiology of metallicolous populations of Cistus ladanifer $\mathrm{L}$. PhD Thesis, University of Santiago de Compostela, Spain

Quintela-Sabarís C, Kidd PS, Fraga MI (2005) Identification of metalliferous ecotypes of Cistus ladanifer L. using RAPD markers. Z Naturforsch 60(3-4):229-235. https://doi.org/10.1515/ znc-2005-3-408

Quintela-Sabarís C, Vendramin GG, Castro-Fernández D, Isabel Fraga M (2010) Chloroplast microsatellites reveal that metallicolous populations of the Mediterranean shrub Cistus ladanifer 
L. have multiple origins. Plant Soil 334:161-174. https://doi. org/10.1007/s11104-010-0368-4

Quintela-Sabarís C, Vendramin GG, Castro-Fernández D, Isabel Fraga M (2011) Chloroplast DNA phylogeography of the shrub Cistus ladanifer L. (Cistaceae) in the highly diverse western Mediterranean region. Plant Biol 13(2):391-400. https://doi. org/10.1111/j.1438-8677.2010.00371.x

Quintela-Sabarís C, Ribeiro MM, Poncet B, Costa R, CastroFernández D, Fraga MI (2012) AFLP analysis of the pseudometallophyte Cistus ladanifer: comparison with cpSSRs and exploratory genome scan to investigate loci associated to soil variables. Plant Soil 359(1-2):397-413. https://doi.org/10.1007/ s11104-012-1221-8

Ramalho PS, Freitas VAP, Macedo A, Silva G, Silva AMS (1999) Volatile components of Cistus ladanifer leaves. Flavour Frag J 14:300-302

Ribeiro S, Delgado F (2016) Cistus ladanifer L. subsp. ladanifer. In: Azevedo L (ed) Cardo. Norprint, Portugal, pp 52-53

Rincón J, Lucas AD, Gracia I (2000) Isolation of rock rose essential oil using supercritical $\mathrm{CO}_{2}$ extraction. Sep Sci Technol 35(16):2745-2763. https://doi.org/10.1081/SS-100102366

Rivas-Martínez S (1979) Brezales y jarales de Europa occidental (Revisión fitosociológica de las clases Calluno-Ulicetea y CistoLavanduletea). Lazaroa 1:5-127

Robles C, Bousquet-Mélou A, Garzino S, Bonin G (2003) Comparition of essential oil composition of two varieties of $C$. ladanifer. Biochem Syst Ecol 31:339-343. https://doi.org/10.1016/ S0305-1978(02)00161-8

Rouy G, Foucaud J (1895) Flore de France ou description des plantes qui croissent spontanément en France, en Corse et en AlsaceLorraine. Imprimerie Deslis Frères, Tours. 2:254-279

Sangswan NS, Farooqui AHA, Shabih F, Sangswan R (2011) Regulation of essential oil production in plants. Plant Growth Regul 34(1):3-21. https://doi.org/10.1023/A:1013386921596

Santos ES, Abreu MM, Magalhães MCF (2016) Cistus ladanifer phytostabilizing soils contaminated with non-essential chemical elements. Ecol Eng 94:107-116. https://doi.org/10.1016/j. ecoleng.2016.05.072

Santos ES, Balseiro-Romero M, Abreu MM, Macías F (2017) Bioextracts of Cistus ladanifer L. growing in São Domingos mine as source of valuable compounds. J Geochem Explor 174:84-90. https://doi.org/10.1016/j.gexplo.2016.07.004

Sebastiani F, Carnevale S, Vendramin GG (2004) A new set of mono- and dinucleotide chloroplast microsatellites in Fagaceae. Mol Ecol Notes 4(2):259-261. https://doi. org/10.1111/j.1471-8286.2004.00635.x

Solano B, Iglesia MTP, Probanza A, García JAL, Megías M, Mañero FJG (2007) Screening for PGPR to improve growth of Cistus ladanifer seedlings for reforestation of degraded mediterranean ecosystems. In: Velázquez E, Rodríguez-Barrueco C (eds) First international meeting on microbial phosphate solubilization. Springer, Dordrecht, pp 59-68

Sosa T, Chaves N, Alias JC, Escudero JC, Henao F, Gutiérrez-Merino C (2004) Inhibition of mouth skeletal muscle relaxation by flavonoids of Cistus ladanifer L.: a plant defense mechanism against herbivores. J Chem Ecol 30(6):1087-1101. https://doi. org/10.1023/B:JOEC.0000030265.45127.08

Sun Y, Skinner DZ, Liang GH, Hulbert SH (1994) Phylogenetic analysis of Sorghum and related taxa using internal transcribed spacers of nuclear ribosomal DNA. Theor Appl Genet 89(1):26-32. https://doi.org/10.1007/BF00226978

Taberlet P, Gielly L, Pautou G, Bouvet J (1991) Universal primers for amplification of three non-coding regions of chloroplast DNA. Plant Mol Biol 17(5):1105-1109. https://doi.org/10.1007/ BF00037152
Talavera S, Gibbs PE, Herrera J (1993) Reproductive biology of Cistus ladanifer (Cistaceae). Plant Syst Evol 186(3-4):123-134. https:// doi.org/10.1007/BF00940792

Teixeira S, Mendes A, Alves A, Santos L (2007) Simultaneous distillation-extraction of high-value volatile compounds from $\mathrm{Cis}$ tus ladanifer L. Anal Chim Acta 584(2):439-446. https://doi. org/10.1016/j.aca.2006.11.054

Thanos CA, Georghiou K, Pantazi C (1992) Cistaceae: a plant family with hard seeds. Israel J Bot 41:251-263. https://doi.org/10.108 0/0021213X.1992.10677232

Trabaud L, Oustric J (1989) Heat requirements for seed germination of three Cistus species in the Garrigue of southern France. Flora 183(3-4):321-325. https://doi.org/10.1016/ S0367-2530(17)31557-8

Valbuena L, Tarrega R, Luis E (1992) Influence of heat on seed germination of Cistus laurifolius and Cistus ladanifer. Int J Wildland Fire 2(1):15-20. https://doi.org/10.1071/WF9920015

Verdeguer M, Blázquez MA, Boira H (2012) Chemical composition and herbicidal activity of the essential oil from a Cistus ladanifer L. population from Spain. Nat Prod Res 26(17):1602-1609. https://doi.org/10.1080/14786419.2011.592835

Vieira M, Bessa LJ, Martins MR, Arantes S, Teixeira APS, Mendes Â, Costa PM, Belo ADF (2017) Chemical composition, antibacterial, antibiofilm and synergistic properties of essential oils from Eucalyptus globulus Labill. and seven mediterranean aromatic plants. Chem Biodivers. https://doi.org/10.1002/cbdv.201700006

Vogt T, Proksch P, Gülz P-G (1987) Epicuticular flavonoid aglycones in the genus Cistus, Cistaceae. J Plant Physiol 131(1-2):25-36. https://doi.org/10.1016/S0176-1617(87)80264-X

Vos P, Hogers R, Bleeker M, Reijans M, Lee T, Hornes M, Frijters A, Pot J, Peleman J, Kuiper M (1995) AFLP: a new technique for DNA fingerprinting. Nucleic Acids Res 23(21):4407-4414. https://doi.org/10.1093/nar/23.21.4407

Weising K, Gardner RC (1999) A set of conserved PCR primers for the analysis of simple sequence repeat polymorphisms in chloroplast genomes of dicotyledonous angiosperms. Genome 42(1):9-19. https://doi.org/10.1139/g98-104

Weyerstahl P, Marschall H, Weirauch M, Thefeld K, Surburg H (1998) Constituents of commercial labdanum oil. Flavour Frag J 13(5):295-318. https://doi.org/10.1002/ (SICI) 1099-1026(1998090)13:5<295:AID-FFJ751>3.0.CO;2-I

White TJ, Bruns T, Lee S, Taylor J (1990) Amplification and direct sequencing of fungal ribosomal RNA genes for phylogenetics. In: Innis M, Geldfand D, Sninsky J, White T (eds) PCR protocols: a guide to methods and applications. Academic Press, San Diego, pp 315-322

Williams JGK, Kubelik AR, Livak KJ, Rafalski JA, Tingey SV (1990) DNA polymorphisms amplified by arbitrary primers are useful as genetic markers. Nucleic Acid Res 18(22):6531-6535. https:// doi.org/10.1093/nar/18.22.6531

Wollenweber E, Mann K (1984) Flavonoid aglycones in the leaf resin of some Cistus species. Z Naturforsch C 39(3-4):303-306. https://doi.org/10.1515/znc-1984-3-418

Zidane H, Elmiz M, Aouinti F, Tahani A, Wathelet J, Sindic M, Elbachiri A (2013) Chemical composition and antioxidant activity of essential oil, various organic extracts of Cistus ladanifer and Cistus libanotis growing in eastern Morocco. Afr J Biotechnol 12(34):5314-5320. https://doi.org/10.5897/AJB2013.12868

Zietkiewicz E, Rafalski A, Labuda D (1994) Genome fingerprinting by simple sequence repeat (SSR)-anchored polymerase chain reaction amplification. Genomics 20(2):176-183. https://doi. org/10.1006/geno.1994.1151 